\title{
COOPERATION AND ISOLATION: UNDERSTANDING EU-RUSSIA DIALOGUE
}

\author{
Anastasia Chebakova \\ University of Victoria
}

\begin{abstract}
The promising agenda of EU-Russia cooperation has resulted in mutual frustration manifested in continuous, paradoxical crises and isolation between the partners. This article offers a possible way to reflect on an uneasy EU-Russia relationship. In this study, I make problems in EU-Russia cooperation discursively visible by scrutinizing the official speech acts articulated in EU-Russia political and security discourse. I demonstrate that these official speech acts create conditions for a responsive dialogue and, eventually, form a set of prevalent discursive practices that re-produce and reinforce problems in EU-Russia cooperation. Blending Bakhtin's dialogic analysis and Onuf's constructivist accounts, I strike a balance between theoretical and empirical analyses and develop a model for understanding current and possible future events in the EU-Russia partnership. This model of international cooperation can be transferable beyond its borders to similar examples of relationships currently existing all over the world.
\end{abstract}


Introduction* $^{*}$

It is entirely your phrase, and not mine.
Your own, and not just the sequel of our conversation.
"Our" conversation didn't take place at all...
- Shatov in Dostoyevsky's "The devils" (The possessed)

(Dostoyevsky and Magarshack 1971, 253).

In less than two decades, the relationship between the European Union (EU) and Russia has been transformed from exclusively bilateral relationships between individual European states and the Soviet Union to a new political reality: an officially declared partnership between the EU and Russia inconceivable during the Cold War period. However, scholarly analysis and conference reports, official statements and public opinion polls demonstrate that EU-Russia relations "are still in a state of protracted crisis" (Report by the Committee "Rossiia v Ob"edinennoi Evrope" (Russia in the United Europe) 2005): legacies of the Cold War era and mistrust between the partners endure, ambiguity of common strategic goals are resurfacing and economic asymmetry continues to exist (Aleseeva 2007; Arbatova 2006, 2008; DeBardeleben 2008; Medvedev 2008; Report by the Committee "Rossiia v Ob'edinennoi Evrope" 2005). A promising agenda of cooperation has tended to result in mutual frustration manifested in continuous, paradoxical crises and isolation between the partners.

This study offers one possible way of reflecting on an uneasy EU-Russia relationship. I make problems in EU-Russia cooperation discursively visible by looking at the EU-Russia political and security dialogue and exploring the following question: What do the official standpoints articulated in the EURussia political and security dialogue demonstrate to us about cooperation between the EU and Russia?

Official standpoints are political statements employed by both the EU and Russia to indicate their strategic choices and articulate their views about cooperation. I demonstrate that these political statements, or "speech acts" (Searle 1969; Bakhtin 1986; Onuf 1989) create conditions for a responsive dialogue and, eventually, form a set of prevalent "discursive practices" (Reiss 1982, 11) that re-produce and reinforce certain modes of thinking in EU-Russia political and security discourse.

In this study, I seek to understand what lies behind the discourse by scrutinizing the interplay of its main components and placing them in the specific context of EU-Russia cooperation. In order to do so, interpretive methodology with textual analysis of political discourse is employed in the study. First, I discuss the theoretical framework chosen in this study in order to reflect upon EU-Russia dialogue in the political and security sphere. Second, I examine selected speech acts and draw a picture of what is produced during the EU-Russia political and security dialogue. In conclusion, I address the paradox of isolation in EU-Russia cooperation and draw implications for future research.

\section{Theorizing EU-Russia Dialogue}

This study employs a constructivist theoretical perspective as an analytical tool to explore the problems in EU-Russia cooperation. Despite the existence of a considerable body of literature (in both English and Russian) on EU-Russia cooperation, the scholars in the area of European and Russian studies have not investigated sufficiently the connection between political dialogue and re-occurring problems in EURussia cooperation. Moreover, neither Western nor Russian scholars make an effort to challenge the assumptions of the mainstream paradigms - "neorealism" and "neoliberalism" - and, therefore, only see EU-Russia cooperation through those conceptual lenses (Prozorov 2006, 2009; Medvedev 2008; Allison et al. 2006). Therefore, given the almost non-existent constructivist agenda in the area of EU-Russia

\footnotetext{
* Author Acknowledgements: I would like to thank Dr. Nicholas Onuf for his much-needed advices and encouragement with regard to publication. I thank Dr. Amy Verdun for her generous support, as well as Dr. Clair Cutler, Dr. Joan DeBardeleben and Dr. Franz Kernic for their suggestions and comments. I owe my gratitude to Dr. William Doll and Dr. Donna Trueit who contributed tremendously to the development of this study.
} 
studies such as agenda can enhance current academic debates by presenting a different view regarding the reasons for growing tensions between the EU and Russia.

This study applies the theoretical assumptions of one constructivist author, instead of trying to generate one more interpretation of "true" constructivism and to test its applicability by fitting the hypothetical reality of EU-Russia relations into the supposedly constructivist accounts. It would not be fair to simplify the arguments and assertions of many constructivists and place them under one monolithic theoretical umbrella - constructivism in IR. ${ }^{i}$ Wendt (1992), Kratochwil (1989), Onuf (1989), or Ruggie (1998) - all played a role in the making of constructivism in the sphere of International Relations. Therefore, it would be more rewarding to consider their arguments in detail instead of making judgements about applicability or inapplicability, "betterness" or "worseness" of one, single constructivist perspective. In this vein, I employ the constructivist approach and the speech act theory offered by Nicholas Onuf (1989) ${ }^{\mathrm{ii}}$ with the goal of revealing a connection between the official speech acts and reoccurring crises in the EU-Russia relationship. While conceiving of EU-Russia cooperation through a constructivist lens, I simultaneously leave space for novelty in my conceptualization, which is informed but not driven by constructivism.

In his understanding of social and political realities, Onuf is concerned with rules that "tell us how to carry on ... in a socially constructed world" (Onuf 1989, 51). People, as well as social constructs such as states, become agents in society through rules. Rules define agents in terms of structure, and structures in terms of agents (Onuf 1998, 64). Moreover, agents act within an institutional and social context, but at the same time they act in this context through deeds. For Onuf, "constructivism begins with deeds" (Onuf 1989, 36). They may consist of words or physical actions (Onuf 1989, 36). Deeds make the world, provide interaction between agents and contribute to the mutual constitution between agents and structure. A speech act as a deed is the "act of speaking in a form that gets someone else to act" (Onuf 1998, 66). Therefore, for Onuf, "the point of a speech act is to have an effect on some state of affairs" (Onuf 1998, 98).

For Onuf, language in a speech act becomes representative and performative: it can be used to perform deeds constituting a social reality and its rules (Onuf 1989, 82). Consequently, an agent can "make" the world not only through its physical actions but also through its speech acts. "The speaking of language is a part of an activity, or of a form of life" (Wittgenstein 1968, par. 23 in Onuf 1989, 44). Consequently, Onuf's speech acts (Onuf 1998, 66) follow the pattern: "I (you, etc.) hereby assert (demand, promise) to anyone hearing me that some state of affairs exists or can be achieved."

Onuf's pattern simultaneously leads in two directions: first, the message sent by the agent needs to be heard by the receiver. As a confirmation, the receiver needs to produce a response back to the agent. Otherwise, any effect of a speech act is questionable. Second, in order to be understood, a speech act needs to be situated in a specific context. Onuf contends that observers can never step outside of the world of constructions: "We can represent the world, including our place in it, through language" (Onuf 1989, 43). However, we "are always within our constructions, even as we choose to stand apart from them, condemn them, reconstruct them" (Onuf 1989, 43).

In the textual analysis introduced in section two, I refer to the classification of speech acts offered by Onuf. According to Onuf's classification (Onuf 1989, 87) assertives are "speech acts stating a belief . . . with the intention] that the hearer accepts this belief"; directives contain an action the speaker wishes the hearer to perform (regulative intent); and commissives consist of the declaration of the speaker's commitment to a stated course of action. Therefore, commissives produce rules for the speaker, whereas assertives and directives try to impose rules on the hearer (Onuf 1989, 87-88). In essence, all three are proactive elements of a speech act.

As described above, Onuf emphasizes the dynamics of discourse, as well as the necessity to explain the performative and transformative impact of language in this discourse. In addition to Onuf, dialogic analysis, as a unique analytical concept introduced by Mikhail Bakhtin (1979), offers a fruitful conceptual and methodological insight to this study. Bakhtin's analysis (Bakhtin 1979, 275) pays attention to responsiveness ("obraschennost", "adresovannost", "Translation mine") in a speech act: the author does not isolate one speaker from the other; instead, he looks at the responsive logic, at reactions 
reflected in the speech acts within one dialogue and, in the case of EU-Russia dialogue, recorded in the official texts. He emphasizes the necessity to talk with someone versus to talk to someone: "he [the main hero] talked with the world, not to the world" (Bakhtin 1979, 275, "Translation mine"). Hence, text can be understood as part of a conversation that reflects dialogic relations ("dialogicheskie otnosheniia", "Translation mine") (Bakhtin 1979, 292, 304), in the case of EU-Russia dialogue, the text of political statements reflects how the partners collaborate. Therefore, Bakhtin's dialogic analysis gives an opportunity to see the relationship that emerges in EU-Russia discourse instead of analyzing the EU's and Russia's speech acts as mechanical statements articulated by partners separately from each other.

"Utterance implies others talking" (Bakhtin 1979, 250, "Translation mine"): from the very beginning it is constructed in consideration of a response; it is "deeply dialogic" (Bakhtin 1979, 275, "Translation mine"). The sender enters into the relationship with the receiver while producing its utterance. Therefore, the process of creating and sending the message is not only proactive, but also reactive in its character. The reactive feature of Bakhtin's utterances does not automatically mean that they lose proactive characteristics described by Onuf; instead, speech acts continue to proactively affect a specific situation, simultaneously having a reactive effect, as contended by Bakhtin. Onuf emphasizes a social action, Bakhtin - a social interaction in the process of communication. The defining principle of Bakhtin's dialogism (dialogichnost", dialogicheskaia aktivnost") is a dialogic interaction (dialogicheskoe obscheniie, "Translation mine") (Bakhtin 1979, 80) with the addressee versus the influence on the receiver of a message.

Thinking in both Bakhtin's and Onuf's terms, EU-Russia discourse is a "social phenomenon" (Bakhtin 1982, 259; Onuf 1989, 31); each political statement in this discourse represents a complete utterance - the unit of analysis in EU-Russia dialogue with a specific goal in a particular sphere of communication. However, for Bakhtin, "it has a meaning, which requires a responsive understanding" (Bakhtin 1979, 305, "Translation mine"). To continue Bakhtin's logic, EU-Russia cooperation presents "the mutual interaction" (Bakhtin 1982, 4) of two voices recorded in the texts of official documents. Each official document in EU-Russia cooperation is not a monologue; rather, it is a part and a result of EURussia dialogue. Textual analysis of these documents helps us understand dialogic relations between the EU and Russia, in particular, information the partners send in their messages to each other and their view about each other and about cooperation. As a result, blending the explanatory power of Onuf's constructivism and the methodological novelty of Bakhtin's theory can break new ground for examining re-occurring crises in EU-Russia cooperation.

In order to provide an account of the effects created by EU-Russia dialogue, it is necessary to address the following questions: how is EU-Russia dialogue produced, and what is the relationship between the sender of a political statement and the receiver of the message? Below is a schematic illustration of the way that I propose EU-Russia discourse is understood in this study. An agent in the dialogue is either the EU or Russia, each of which manifests its own world-views, its vision of the partner or of cooperation in the selected speech act. The preliminary structure of the relationship between the speaker (agent) and the receiver of the speaker's message (other) can be portrayed as follows: 


\section{Speaker}

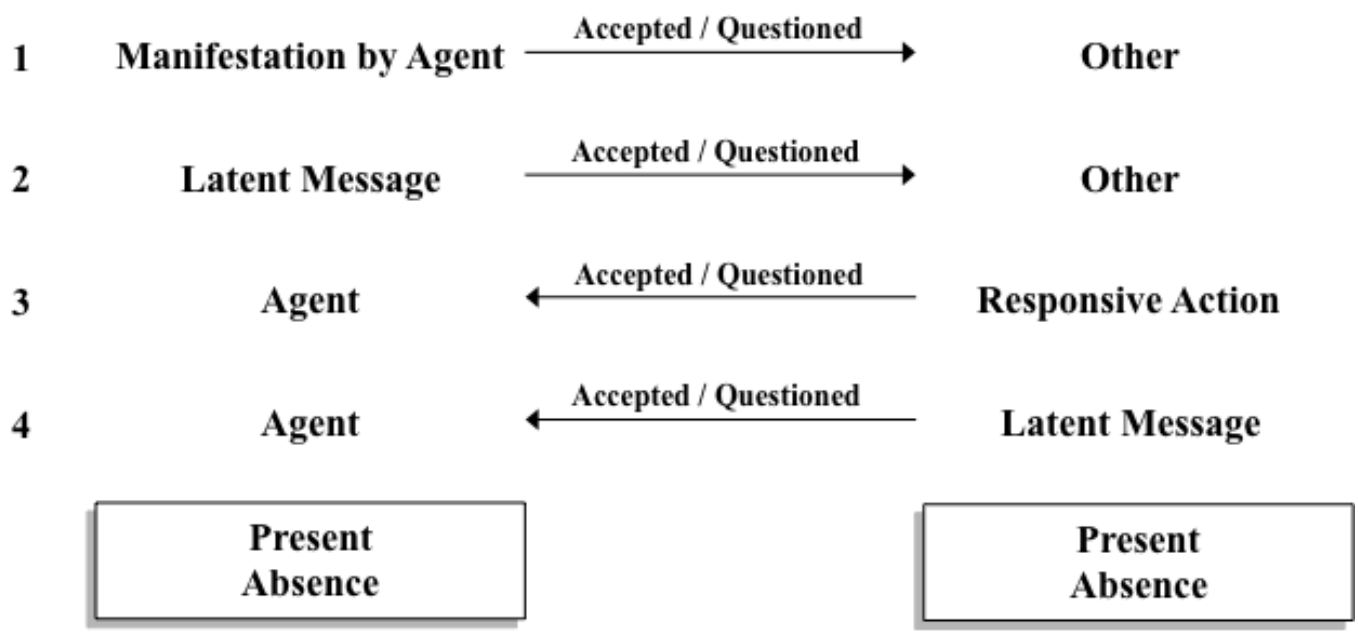

\section{Receiver}

\author{
Other
}

Other

Absence

Line 1 in the diagram above, "manifest speech act by agent", indicates that the agent manifests its view on the current or desired state of affairs in its symbolic message sent to the receiver, calling its conversant into action. However, line 2, "latent message", shows that there is some information or knowledge that is left latent in the agent's speech act. For instance, presumptions that are implied by the agent as a self-evident truth and, therefore, not problematized in its message. The response by the receiver may or may not question the latent message sent together with the agent's manifest deed. The success of the agent's speech act depends not only on receiving a response back from the conversant, but also on the consenting or non-consenting character of this response. The agent's speech act is aimed at successfully indoctrinating the agent's view; I examine what and how much of the information within the agent's message the receiver questioned. I also scrutinize the success or failure of manifest deeds and indoctrinations voiced by both partners.

In lines 3 and 4 of the diagram, the receiver sends its manifest speech act together with a latent message back to the agent in the response format. "Present absence" in the diagram is a non-articulated position or view intentionally repressed by both the speaker and the receiver in their manifest speech acts. I examine whether the tension in cooperation occurs during the process of production of the response by "the other" and the subsequent acceptance or refusal of this response by the agent. Even if the indoctrination is completed successfully, it may create the split in the receiver's personality: the receiver has to accept the agent's view and to produce a response alienated from the receiver's "self". To demonstrate the way in which scrutinization of EU-Russia discourse may help to understand re-occurring crisis in EU-Russia cooperation, I next turn to analysis of the EU-Russia political and security dialogue, leaving space for the emergence of new elements in the structure of EU-Russia discourse suggested above.

\section{Analyzing Isolation and Cooperation}

I examine the EU-Russia interaction articulated in the official declarative statements, excluding the analysis of all other speech acts available within the framework of cooperation. The official standpoints not only provide the formal legal context of cooperation, but they also construct the political environment for the EU-Russia relationship, create new structural conditions, alter or reproduce perceptions of the partners about each other and their cooperation. Moreover, these key primary sources reflect the internal negotiations and "basic discourses [about things] that are considered to be viable, desirable and necessary" (Hansen 2006, 51-2); they reflect official discourse between the EU and Russia. 
The starting point of my analysis is that "all actions by human beings involved with others in a social group are, as Bakhtin (1986) claims, dialogically and responsively linked in some way, both to the previous already executed actions, and to anticipated next possible actions" (Shotter 1995, 49). Following this logic, the aforementioned political statements are related to each other within the framework of one conversation between the EU and Russia and involve "shared intentionality" (Searle 1992, 21-2). It means that they are not a matter of an individual speech act or an individual intention; rather, they are representations of a conversational, dialogic activity. This interrelatedness of political statements in EURussia dialogue, currently overshadowed by the central focus on individual interests and intentions in political and academic discourse, is very important for understanding EU-Russia cooperation.

In order to sharpen the analytical focus, I search for answers to the following questions that serve as a guide for analyzing the selected key texts:

- Perception of "self" and "other". What perceptions and representations of "self" and "other" emerge in EU-Russia dialogue? Is there any contradiction in partners" perceptions? Indeed, the way the EU and Russia perceive each other is indicative of their own worldviews and political thinking. Therefore, in order to understand what partners "think" of themselves (their self-image) and of the other (their partner), I examine information that Russia and the EU communicate about each other.

- Expectations and goals. What do the EU and Russia expect to happen as a result of their cooperation? What do the EU and Russia aim for in their cooperation?

- Latent message. What do the partners take to be a self-evident truth in the texts of political statements and, therefore, do not problematize in their messages to each other?

- Absent presence. What goes unsaid in the EU's and Russia's messages to each other?

- Outcome. What do both partners mutually produce as a result of their dialogic relations?

- "The significant third". Do the EU and Russia refer to something or somebody in their speech acts towards each other? Is the relationship between the two partners influenced by a "third?"

\section{The Partnership and Cooperation Agreement}

The growing speed of European integration and the establishment of the EU in 1992 with its powerful economy, wider responsibilities and growing political weight made it necessary for a resurgent Russia to set up a coherent policy framework and institutionalized cooperation with its powerful Western neighbour. The Partnership and Cooperation Agreement (The Agreement, PCA), signed in 1994 and adopted in 1997 for the period of 10 years (The Partnership and Cooperation Agreement (PCA) 1997) forms a legal basis for EU-Russia relations and creates structural-institutional conditions for cooperation. The Agreement has continuing importance as the two parties are now in the process of negotiating a new one. The adoption of a PCA opens up a new EU-Russia dialogic space symbolizing the beginning of interaction. I understand this joint statement through the lens of Bakhtin's concept of polyphony (Bakhtin 1979, 6): two independent voices speaking simultaneously but distinct from each other in a double-voiced discourse. In order to examine the EU-Russia interaction in this double-voiced joint statement, I will apply the afore-mentioned discursive interaction model.

How do the EU and Russia present themselves in the Agreement? The text of this document is replete with articles based on principal-agent relations: the EU acts as an invisible principal whose mission is to spread its democratic and liberal economic rules across the territory of Russia, whereas Russia plays the role of a silent agent, which needs to follow the EU's directions. In the text of the Agreement, Russia's political and economic reforms become the prerequisite for EU-Russia cooperation, and Russia's one-sided transformation appears to be the only requirement for the success of EU-Russia cooperation (PCA 1997, Preamble; Article 6). As a result, the EU sets up the basis for its superiority in cooperation; transformation or change within the framework of the EU-Russia partnership becomes an exclusive burden for Russia, not for the EU. Therefore, the superiority of the EU is not problematized in the Agreement constituting the PCA's latent message. 
What is the EU's emergent "self'? Paradoxically, the EU's self-representation in the Agreement is itself blurry: it can be "the commitment of the Community and its Member States acting in the framework of the European Union by the Treaty on European Union of 7 February 1992" (PCA 1997, Preamble), or the will of the member-states, or even the actions of the Community alone. Throughout the document, the EU does not refer to itself as the EU, which indicates the ambiguity of its own selfidentification. Such an ambiguity in EU identity is understandable when placed into the historical context of the EU's internal development. ${ }^{i i i}$ This ambiguity, however, provides the EU with freedom for manoeuvre hiding the EU's inability to speak with "one voice" within the framework of EU-Russia dialogue. As a result, problems with the EU's ongoing transformations and with ambiguity of its international identity remain unsaid in the PCA.

What are the partners' expectations voiced in the Agreement? Partners anticipate that cooperation will deepen and widen relations established between them in the past: it will lead to strengthening political and economic freedoms (PCA 1997, Preamble, Article 1) and to increasing stability and security (PCA 1997, Article 6). In the text of the Agreement, partners express their belief that by developing regular political dialogue and intensifying political relations (PCA 1997, Preamble, Article 1, 6), increasing convergence on international issues (PCA 1997, Article 6) and developing economic cooperation (PCA 1997, Preamble; Article 1), a gradual rapprochement between Russia and Europe as the main goal of cooperation can be reached (PCA 1997, Preamble). The partners also proclaim the basis of cooperation to be the principles of mutual advantage, mutual responsibility and mutual support (PCA 1997, Article 1). As an outcome of cooperation, they expect closer integration between Russia and a wider area of cooperation in Europe, as well as the future establishment of a free trade area between the European Community and Russia (PCA 1997, Article 1).

Despite the expressed claims for mutuality in cooperation, Russia does not seem to articulate any views or concerns of its own in the text of the Agreement. The historical context helps us to understand the silence from the Russian side. While the agreement was being negotiated, Russia was going through a transition period and it could not afford to miss the chance to establish a new connection with its powerful neighbour, which could potentially provide plenty of economic and technical support for Russia. ${ }^{\text {iv }}$ Perhaps driven by the fear of disconnectedness, Russia intentionally occupied a "silent" position and agreed to act as an "unequal" partner and a passive receiver of the EU's directions. As a result, the mutually produced Agreement allowed for the EU's emergence of "self", somewhat superior in relation to Russia as a silent "unequal other". At the very early stage of EU-Russia cooperation, both partners laid the basis for a potential future conflict.

In the text of the Agreement, partners consent to "[promote] regional cooperation" (PCA 1997, Article 56 (3)) and commit to collaborate in the framework of the United Nations, the Conference on Security and Cooperation in Europe (CSCE) and other fora (PCA 1997, Preamble). The image of the "third" - the international community and the closest neighbours - is non-conflictual in the text of the PCA.

To sum up, in Onuf's classification, the Partnership and Cooperation Agreement represents the type of commissives, which consist of partners' mutual declaration to cooperate in order to achieve further rapprochement. However, it carries some elements of assertives and directives with the intent from the EU's side to regulate transformation and modernization of Russia.

\section{Common Strategy of the European Union on Russia}

In 1999, the EU adopted the second fundamental document in the EU-Russia relationship - the Common Strategy of the European Union on Russia (Common Strategy of the European Union on Russia 1999 (EU Common Strategy, Common Strategy)). In its Common Strategy, the EU gave its response to the dialogue started in the PCA by sending the message to its receiver - Russia; the PCA and the Common Strategy are dialogically linked within one EU-Russia conversation. Moreover, the EU's Common Strategy is not only a reactive response to the PCA; it is also a proactive message sent from the EU to Russia in anticipation of a Russian response. Indeed, the EU's political statement exemplifies well, both the 
proactive and reactive nature of speech acts. Due to size limitations, this study will focus only on the official dialogue between two conversants - the EU and Russia - and will not analyze the fact that the EU's message may indirectly be voiced for the multiplicity of listeners (i.e., other neighbouring countries).

The Community and its member states, through the Common Strategy finally, transform into one voice - the EU. It is the EU that articulates the "vision...for its partnership with Russia" (EU Common Strategy 1999, Part I) in the Common Strategy. It is the EU that "[invites] Russia to work" together on the basis of the Common Strategy (EU Common Strategy 1999, Part I). It is the Union's actions and institutions that implement provisions of the Common Strategy (EU Common Strategy 1999, Instruments and means (1)). The EU's "self" also crystallizes in the Common Strategy through its relation to the "other". The EU draws a clear image of Russia as a desirable partner: this image is based on what the EU "is" and what Russia "is not". In analogy to the EU's vision of Russia articulated in Part one "Vision of the EU for its partnership with Russia," the Union can be characterized as a "stable democracy . . . governed by the rule of law and underpinning a prosperous market economy" (EU Common Strategy 1999, Part I "EU's strategic goals"). This implicit assumption by the EU about itself underlines the logic of the Common Strategy and plays a role of the latent message sent to Russia.

In its message towards Russia, the EU clearly draws the image of Russia that it welcomes as a friend. It is a "stable democratic and prosperous Russia" (EU Common Strategy 1999, Part I), which "rightfully" belongs to "the European family" (EU Common Strategy 1999, Part I) and "asserts its European identity" (EU Common Strategy 1999, Part I). Paradoxically, the "paramount importance of the rule of law and respect for human rights . . . and market economy" written down earlier in the PCA (PCA 1997, Preamble) in the Common Strategy becomes a pre-condition which Russia must fulfill in order to finally occupy its "rightful place in the European family" (EU Common Strategy 1999, Part I). In the Common Strategy, the EU crystallizes its perception of Russia and strengthens its "conditional" attitude towards the partner as an "unequal other." The language of the EU's political statement aims to have the effect of a prescription, a directive issued to the hearer (see Onuf's classification). In Russia's response, it will become obvious whether the EU's directive is followed, followed with amendments, or completely rejected.

What goals and expectations does the EU articulate in the Common Strategy? The EU defines modernization of Russia as its strategic interest in the framework of the EU-Russia partnership (EU Common Strategy 1999, Preamble). It expects Russia to "consolidate democracy and the rule of law," mentioned earlier in the PCA, through the building of civil society and "the establishment of public institutions" (EU Common Strategy 1999, Part 1). Provided Russia acquires the necessary features to become treated as a "friend," partners have a chance to establish a strategic partnership and to cooperate on "the New European Security Architecture" (EU Common Strategy 1999, Part II). Hence, the goal of the EU's Common Strategy is to clarify and define the exact criteria that Russia needs to meet in order to become partners with the EU and to build "a common European economic and social area" (EU Common Strategy 1999, Principle objectives (2)).

The EU aspires to build cooperation "benefiting alike all the people of Russia and of the European Union" (EU Common Strategy 1999, Part I). In its message, however, the EU explicitly demonstrates that "the main responsibility for Russia's future lies with Russia itself" (EU Common Strategy 1999, Part I), which means that any deviations in the Russian course of transformation become an individual responsibility of Russia. In this vein, the main agent's (EU) message can be defined as follows: in order to be given an opportunity to cooperate with the EU, Russia needs to modernize and be responsible for its own modernization itself. Sending this message, the EU demonstrates an individual intention rather than mutuality in its cooperation with Russia. By sending such a message to its partner, the EU hinders the interrelatedness in EU-Russia dialogue, and the very spirit of mutuality and cooperation as the "operation together" is absent.

When compared with the PCA, the EU's Common Strategy prescribes even more importance to the "continuity, flexibility and substance" (EU Common Strategy 1999, Part III) of the existing political dialogue with Russia. What remains "unsaid" in the EU's message towards Russia? The EU talks about 
common interests in addressing common challenges on the European continent and common problems with money-laundering, illegal trafficking, drug trafficking, organized crime, energy resources etc (EU Common Strategy 1999). However, the EU does not talk about conflicting interests; it only articulates the changes that Russia needs to make in order to become closer (i.e., similar) to the EU, or it opens up discourse on "commonality" between the partners as the symbol and guarantee of the future success in cooperation. As a result, differences between the partners remain "indefinable" in the EU's message because they are perceived by the EU as the factors that hinder the effectiveness of EU-Russia cooperation; the factors that interfere with the EU's intentions to homogenize and "commonalize" EURussia cooperation, and, therefore, need to be absent in EU-Russia dialogue.

As in the PCA, the EU discusses and expands on the notion of "regional cooperation", promising to promote cooperation with Russia in "the various fora for regional cooperation [e.g., Barents EuroArctic Council, Organization of the Black Sea Economic Cooperation]" and to enhance the "cross-border cooperation with neighbouring Russian regions (including Kaliningrad)" (EU Common Strategy 1999, Part II "Areas of action" (c)) - all appropriated in view of the EU's enlargement. Therefore, initially "neutral" reference to the "third" in the PCA - i.e., international institutions and neighbouring countries changes into an exclusive domain of the EU's enlargement policy in the EU's Common Strategy. Moreover, the EU is ready to enhance EU-Russia cooperation in the area of preventive diplomacy by contributing to conflict management and "curbing the proliferation of WMD [weapons of mass destruction]" within the Organisation for Security and Cooperation in Europe (OSCE, formerly known as CSCE) and the United Nations (UN) (EU Common Strategy 1999, Preventive diplomacy). However, the EU leaves out of its message a discussion of the role of the North Atlantic Treaty Organization (NATO) due to the fact that this organization represents an extremely conflictual "third". Indeed, the discussion about NATO within the framework of EU-Russia dialogue can be conceived as problematic for the EU's own internal development, for instance, the formation of the European Security and Defence Policy as a security and defence component in the EU's architecture that is supposedly independent from NATO. The discussion about NATO becomes even more conflictual for the EU's external collaboration with Russia whose interests fall far short of NATO.

In sum, the EU's Common strategy, containing a set of criteria for actions that the EU wants Russia to perform, provides a good example of a directive speech act (Onuf, classification: section 1). The part of the EU's message about the importance of the rule of law, democracy and human rights carries insignificant elements of assertives (see Onuf's classification: section 1). As a result, the EU's Common Strategy reinforces the "principal-agent" discursive practice introduced earlier in the Partnership and Cooperation Agreement.

\section{The Russian Federation Middle Term Strategy Towards The European Union}

The adoption of the Russian Federation Middle Term Strategy towards the European Union (2000-2010) (The Russian Federation Middle Term Strategy Towards The European Union 1999 (The Russian Strategy)) affirms careful attention of Russia towards cooperation with the EU and recognition of the EU's status as a partner (Russian Strategy 1999, Preamble).

In its Strategy, Russia portrays itself as a sovereign nation-state, which has a consistent foreign policy and a developed, coordinated approach towards Europe that echoes its National Doctrines ${ }^{\mathrm{v}}$ (Russian Strategy 1999, Preamble). Moreover, Russia clearly points out that the EU-Russia partnership is not aimed at "Russia's accession to or "association" with the EU" (Russian Strategy 1999, Part I). This statement has an important declarative meaning in Russia's response to the EU: it is a manifesto of the Russian resistance and refusal to adopt a "submissive" position in the EU-Russia partnership.

Russia perceives the EU as a group of European nation-states (e.g., "common histories of nations," "responsibility of European States" (Russian Strategy 1999, Preamble)) rather than a "non-traditional," "post-modern," or "post-national entity" (Smith 2003; Ruggie 2000). To put it simply, Russia perceives the EU through the lens of its own concept of the sovereign nation-state, which it attempts to build in a coherent manner. 
In response to the EU's strategic interest in Russia's modernization articulated in the EU's message, Russia explicitly replies that it is not only Russia, but also the EU who needs to transform or change in order for successful cooperation to occur (Russian Strategy 1999, Preamble).

Moreover, Russia seeks to "protect Russia's national interests in cooperation" (Russian Strategy 1999, Preamble) during the difficult period of Russia's transition. In "securing the Russian interests in an expanded European Union" (Russian Strategy 1999, Section 5), Russia demonstrates the will to "[eliminate or set off] possible negative consequences" (Russian Strategy 1999, Section 5) of the EU's expansion. As a result of EU-Russia dialogue, in its response to the EU, Russia acquires a voice: the voice of resistance and defence.

In the text of its Strategy, Russia treats the EU as a source of modernization "[mobilizing] the economic potential and managerial experience of the EU" (Russian Strategy 1999, Preamble) within the framework of the partnership. Such an instrumental rhetoric about the EU as a source rather than a partner exemplifies that Russia simply "responds with the same coin" to the EU's individualistic approach to cooperation demonstrated in the EU's Common Strategy. As a result of EU-Russia dialogue, both partners gradually lose the very spirit of "operating together" in their messages to each other. They establish the relationship based on the model of one partner attempting to impose and another, to resist. Moreover, the EU's and Russia's self-presentations co-emerge in EU-Russia dialogue according to the same model of one partner dominating and another counteracting.

In section two of the document, Russia accepts the EU's willingness to continue developing the political and security dialogue and joint foreign policy initiatives. It also recognizes and successfully accepts the necessity of institutionalization of EU-Russia dialogue expressed in the EU's political message to Russia. As well, the EU achieves a great success in the part of its message concerning the establishment of the New European Security Architecture (EU Common Strategy 1999, Part II). Russia places a great emphasis on "building pan-European Security" (Russian Strategy 1999, Section 1 (5), (8)) together with the EU and establishing a pan-European economic and legal infrastructure. However, Russia continues to stress the importance of "taking into consideration Russia's concerns" in the EU Russia dialogue, securing Russia's interests and emphasizing differences existing between partners unsayable in the EU's message (Russian Strategy 1999, Section 2).

The Russian response clearly voices what remains "unsaid" in the EU's message. In its Strategy, Russia openly reflects on the EU's ambiguous, flexible and unstable identity in the sphere of defence and security, and the potential this ambiguity and indefiniteness can provide in establishing, jointly with Russia, the new security architecture in Europe. Moreover, Russia openly discusses the creation of the new security architecture as a possible counter-balance to NATO centrism in Europe - the topic that is largely conflictual and, therefore, "absent" in the EU's message (Russian Strategy 1999).

Russia responds to the notion of "common" in the EU's message, only briefly mentioning "common histories of [European] nations... and complementarity of their economies" (Russian Strategy 1999, Part I). In section twelve "Ensuring the implementation of the Strategy inside Russia" (Russian Strategy 1999, Section 12), Russia temporarily abandons its "exceptionalist" and "particularist" position that is latently present in the Russian response to the EU, trying to emphasize interrelatedness and interconnectedness between the partners. Russia clearly states that its own modernization and the success of EU-Russia cooperation depend on an "evolution within the EU," "development of international situation" and an outside "organizational, legal and material support" for change in Russia (Russian Strategy 1999, Section 12 (1)), rather than on a one-sided transformation of Russia by itself. By refusing to accept the EU's demands to look out for itself, Russia demonstrates how its own internal change is interrelated with a number of outside factors.

In its message, Russia responds not only to the EU's Common Strategy, but also to the starting point of EU-Russia dialogue - the PCA. It demonstrates a very pragmatic approach to the PCA emphasizing that "the Russia - EU partnership should be based on the maximum use of benefits offered by the PCA and the fullest possible realization of its provisions and follow-up goals" (Russian Strategy 1999, Part 1(4)). However, the discussion of specific internal problems and the domestic situation in Russia, mentioned in both the PCA and the EU's Common Strategy, is absent in Russia's response. 
Apparently, keeping internal problems in silence helps Russia to make its "loud response" on the EU's message less vulnerable to the critique from the EU.

Russia refers to the wider international community in the text of its response to the EU. For instance, "the protection of national production in certain sectors of economy is justified, subject to international law and experience," or "Strategic partnership with an emphasis on supremacy of international law" (Russian Strategy 1999, Preamble). Suddenly, the "third" acquires significance in building cooperation with the EU: Russia refers to the abstract symbolic image of the international community, international law and international society as its last resort, the escape.

The analysis of the Russian Strategy shows that Russia, to some extent, committed to the EU's course of action; the EU's directive did succeed in encouraging Russia to send the response and to voice its own view. Russia's speech act signifies a reactive-resisting action and a proactive-assertive action with the intent to make the hearer accept Russia's equality, views and beliefs. Therefore, assertives and commissives are the two main elements of Russia's speech act (see Onuf's classification). An assertive action signifies Russia's understanding of the necessity to interrelate partners' positions, to build some kind of mutuality and to "travel together" rather than "walk apart". Furthermore, Russia's declaration expresses desire and commitment to future cooperation with the EU. However, the number of issues raised by the EU's message and questioned or even explicitly rejected by Russia's response makes the success of the EU's directive questionable. As an outcome of the dialogue, Russia's Middle Term Strategy demonstrates that the EU did not completely succeed in trying to build EU-Russia dialogue on the basis of its directives and the dominant attitude towards Russia. With the exception of an insignificant attention paid by Russia to the necessity of interrelatedness and sincere "operation together", both partners tend to treat the partnership instrumentally. The EU's response to the Russian Strategy will inform whether the Russian "loud message" results in weakening or strengthening the discursive practice introduced in the PCA and reinforced by the EU's Common Strategy.

\section{EU's Country Strategy Paper}

Contrary to the previous documents, in its Country Strategy (2007-2013) adopted in 2007 (Country Strategy Paper: Russian Federation 2007 (Country Strategy Paper)), ${ }^{\text {vi }}$ the EU starts to recognize its internal problems speaking more openly about its own "self": "the EU seems a great deal weaker following its constitutional crisis (it is already clear that the Kremlin considers Berlin, London, Paris and Rome of more significance than Brussels)" (Country Strategy Paper 2007, Section 3(2)).

Russia succeeds in its assertive action aimed at the "improvement of the image of Russia in Europe" (Russian Strategy 1999, Preamble) leading the EU to change its perception about Russia. For instance, the EU recognizes that Russia "becomes more assertive" (Country Strategy Paper 2007, Section 3(2)) and "[has improved] financial position on the back of substantial energy export revenues, its economic standing as a member of the G8, and indeed its sheer size" (Country Strategy Paper 2007, Section 2). Moreover, Russia's proactive response in its claims for equality with the EU leads to a recognition of Russia as a "key ally in EU efforts to combat new threats to security, crime terrorism" (Country Strategy Paper 2007, Section 3).

The EU, however, continues to apply its own well-developed criteria for democracy to Russia. Although the EU claims that "it cannot take Russia for granted" "as Russia becomes more assertive" (Country Strategy Paper 2007, Section 3.2), latently, the EU continues to conceive of Russia in terms of an "unstable", "undemocratic", "unlawful" country, repeatedly pointing out in the document that "Russia is characterized by a powerful bureaucracy, a politically-biased legal system, powerful and repressive law enforcement agencies and a relatively weak civil society" (Country Strategy Paper 2007, Summary; Section 4.1). The "political opposition remains weak and fractious" in Russia (Country Strategy Paper 2007, Section 4.1), and there is a lack of independent media (Country Strategy Paper 2007, Section 3.1; 4.1).

In comparison with its Common Strategy (1999), the EU pays noticeably more attention to Russia's actions, goals and the trends of its development. For instance, the EU frequently says "Russia 
seems to be ...", or "the signs are that Kremlin . . " (Country Strategy Paper 2007, Section 3.2). However, the level of the EU's uncertainty of "what Russia really is" is one more result of the lack of communication in EU-Russia dialogue.

In its Country Strategy Paper, the EU seeks to generate "a robust and coherent approach to the EU relationship with Russia" (Country Strategy Paper 2007, Section 2) based on all documents issued by the EU towards Russia (e.g., PCA, Common Strategy), or wider EU neighbourhood (e.g., EU Neighbourhood policy, 2004), or the rest of the world (e.g., European Security Strategy 2003). Apparently, the EU has an ambition to build its new self-image as an international actor that has a strong external foreign policy based on a "policy mix" (Country Strategy Paper 2007, Section 6.1). However, it remains uncertain whether the new EU international identity is accepted or rejected by Russia.

Paradoxically, the reference to the Russian Strategy is absent in the EU's Country Strategy Paper, which indicates that the EU treats its political statement as an individual speech act outside of the EURussia dialogue. In other words, the EU tries to distance itself and to become "internally closed" (vnutrenne zamknutym, "Translation mine") (Bakhtin 1979, 81) in order to "think" about Russia more neutrally, more objectively. Such a trend in the EU's responsive action undermines the very possibility for interrelatedness in EU-Russia cooperation.

The EU's definition of cooperation in the Country Strategy Paper sets up the requirement of commonality as a prerequisite for the success of the EU-Russia partnership; it identifies the components of cooperation (interests and values) that should be in common between the two partners in order to, firstly, meet the EU's requirement and, secondly, to succeed in EU-Russia cooperation (Country Strategy Paper 2007, Section 2). ${ }^{\text {vii }}$ Once introduced, the concept of commonality "naturally" starts playing a special role as the latent message in the EU's message to Russia. Conflicting interests and other differences between the partners become objectified in the EU's discursive practices as a self-evident obstacle to the success of cooperation.

Furthermore, the EU widely discusses in its Country Strategy Paper all Russia's conceivable problems that are absent from the text of Russia's Strategy. Time and again, the EU emphasizes that Russia is solely responsible for all these problems, and the EU's exclusive role is to provide financial assistance according to numbers carefully written down in the EU's Country Strategy Paper (Country Strategy Paper 2007, Section 1, 2). However, the notion of mutual responsibility and interrelatedness is again left out of the EU's message, with the exception of several moments in the text when the EU is talking about "mutually-beneficial engagement with . . . the Russian government" or "a spirit of . . . mutual self-interest" in cooperation (Country Strategy Paper 2007, Section 6). Instead of the cooperative rhetoric in the EU's voice, the section "lessons learned" (Country Strategy Paper 2007, Section 5.2) demonstrates well the EU's talents in monitoring, evaluating and managing its instrumental financial support rendered to Russia (Country Strategy Paper 2007, Section 5.2).

In the EU's Country Strategy Paper, relations with the "third" - neighbouring countries to the south and east - become an exclusive domain of the EU's Neighbourhood Policy (Country Strategy Paper 2007, Section 5.2). All other relations with the "third" are regulated under the framework of the EU Common Foreign and Security Policy, as well as the European Security and Defence policy. The EU aspires to appropriate its relations with the "third" outside an EU-Russia dialogue. Russia, for its part, has little to add as "a strategic partner" to all the spectrum of EU policies adopted and implemented without Russia's participation and outside of the framework of EU-Russia cooperation.

To sum up, the EU's Country Strategy Paper is an example of assertives and directives in Onuf's classification: it asserts that Russia must accept the EU's view of EU-Russia cooperation as a strategic partnership founded on shared interests and common values. The Country Strategy Paper also sets up several instruments for regulating the state of democracy in Russia (e.g., Country Strategy Paper 2007, Section 6.4-6.7) and directing EU-Russia cooperation towards the creation of Common Spaces (Country Strategy Paper 2007, Section 3.7). Despite the fact that the EU responded and partially recognized Russia's "equal but different" status, Russia was not able to weaken the EU's discursive practice launched in the PCA, reproduced in the EU's Common Strategy in 1998 and reinforced later in the EU's Country Strategy Paper. 


\section{Concluding Remarks}

"The body" of EU-Russia cooperation is its legal and institutional framework established by both partners. In this study, I examined "the face" of the EU-Russia partnership and expressions it gains in the process of dialogic interaction. The goal was not to overload the reader with new facts about the partnership but to engage closely with official texts as the carriers of EU-Russia conversation. As results of textual analysis have shown, the way the EU and Russia practice their speech acts is conflict-creating and crisis-prone: it produces mutual frustration and distance between the partners. However, the paradox of isolation in EU-Russia cooperation disappears with a closer look at partners' dialogic relations: these relations continuously reproduce inequality and asymmetry, dominance and resistance, inevitably leading to re-occurring tensions in EU-Russia cooperation.

Examination of EU-Russia dialogue revealed that Russia tried to strongly resist inequality and asymmetry announced at the very first stage of EU-Russia cooperation (PCA), whereas the EU repeatedly re-established this inequality and asymmetry with all the means at its disposal. By applying such tactics, Russia did not succeed in its attempts to discursively position itself in EU-Russia dialogue. The EU, for its part, did not succeed in its efforts to use the power of norms, rules and economic instruments to exercise control and homogenise the cooperative space with Russia. Finally, both partners did not succeed in "operating together" and creating a common space of mutuality, understanding and acceptance. Instead, they succeeded in co-creating the images of an "exceptionalist" Russia, claiming for a special qualitatively different status of independent sovereign state, and an "individualist" EU, prioritising an individual intention over mutuality in cooperation with Russia, thereby increasing the gap between the two.

By agreeing to cooperate, the EU and Russia have taken a step towards introducing new practices in the world of international politics; they created the common space of cooperation. The very possibility of cooperation has been conditioned by both the EU's criteria imposed on Russia to be considered as a friend and by Russia's claims for equality with the EU. However, both sides are responsible for the final outcome of their dialogue. Both are responsible for the improvement in communication. Both partners need to make cooperation work, without declaring their differences irreconcilable, and without overemphasizing the numerous gaps that exist between them. Rather, each partner needs to utilize these differences to discover a way to exist alongside a very different "other".

Despite re-occurring problems in cooperation, both partners have an opportunity to view their cooperation as an open concept for re-thinking and re-definition. The scheme of analysis offered in this study may serve as a model for understanding possible events in EU-Russia cooperation: whether it is a new strategy from Russia's side or the adoption of a new Partnership and Cooperation Agreement. This new Agreement has a symbolic sense of continuation. It is not a "final say" in EU-Russia dialogue; rather, it is a "new" beginning:

When dialogue ends, everything ends. Thus dialogue, by its very essence, cannot and must not come to an end. (Bakhtin 1984, 252).

\section{NOTES}

${ }^{\mathrm{i}}$ Some authors (Checkel, 2004; Zehfuss 2002, 10) make an effort to define at least "three constructivisms". For instance, Checkel $(2004,3)$ offers a distinction among conventional, interpretative and critical (radical) variants. Others (Fierke 2007, 174) suggest a dichotomous division into "conventional" and "consistent" constructivism: "the former [accepts] the existence of an objective world, while the latter [emphasizes] "merely" language". Barnett (2005) and Wendt (1999) attempt to integrate diverse theoretical arguments and to draw a picture of one constructivist theoretical paradigm.

ii The word "constructivism" was initially introduced to IR by Nicholas Onuf in 1989 (Fierke 2007, 172). 


\footnotetext{
iii The European Union was established only in 1993 with the Maastricht Treaty entering into force and introducing the EU as a new actor searching for its own niche, its own identity in the world of global politics.

iv The EU's assistance is later rendered through such programs as: TACIS, INTERREG I. II, III, ENPI etc. According to some scholarly research, the amount of such assistance from the EU's side is not sufficient enough to make a difference (e.g., Pashkovskaia 2007, 42-51).

${ }^{v}$ Several National Doctrines including the Foreign Policy Concept of the Russian Federation. (2000) were issued around the same period as the Russian Strategy during the first term of Vladimir Putin's presidency.

${ }^{\mathrm{vi}}$ The Road Maps of Four EU-Russia Common Spaces (2005) jointly developed with participation of both sides (e.g., St Petersburg Summit, 2003 and 2005, the work of the Joint Working group on the creation of the Common Economic Space) acquired a different meaning for the EU and became 'an expression of EU policy towards the Russian Federation . . . a robust and coherent approach to Russia' (Country Strategy Paper, 2007) - i.e., the EU's unilateral response towards Russia. The ambiguous status of this document within the framework of EU-Russia partnership does not allow me to include it as a clear example of the EU's response to the Russian political statement.

${ }^{v i}$ The text of the Country Strategy Paper itself confirms my choice of the EU's responsive speech act: "the road maps remain, in any event, the short and medium term instruments for the EU-Russia relationship, and this is likely to be confirmed in the new agreement" (Country Strategy Paper 2007, 7).

${ }^{\text {vii }}$ The EU defines EU-Russia cooperation as follows: "EU cooperation with Russia is conceived in terms of, and is designed to strengthen, a strategic partnership founded on shared interests and common values" (Country Strategy Paper 2007, Section 2).
}

\section{REFERENCES}

\section{SECONDARY SOURCES}

Aleseeva, T. 2007. "Rossiia v prostranstve globalnogo vospriiatiia." Mezhdunarodnye Protsessy 5 (2/14). Accessed August 25. http://www.intertrends.ru/fourteen/005.htm.

Allison, R., M. Light, and S. White. 2006. Putin's Russia and the Enlarged Europe. Wiley-Blackwell. Arbatova, N. 2006. "Obshchee politicheskoe prostranstvo mezhdu Rossiei i ES: utopiia ili real'nost." Mirovaia Ekonomika I Mezhdunarodnye Otnosheniia 12: 3-12. (Arbatova N. 2006. "Common Political Space between Russia and the EU: Utopia or Reality." World Economy and International Relations 12: 3-12.)

Arbatova, N. 2008. "Obshchee prostranstvo bezopasnosti mezhdu Rossiei i ES: imperativy i pripiatstviia." Indeks Bezopasnosti 3 (86/14): 63-76. (Arbatova N. 2008. "Common Security Space between Russia and the EU: Imperatives and Obstacles." Security Index 3 (86/14): 63-76.)

Bakhtin, M. 1979. Estetika slovesnogo tvorchestva. Moskva. (Bakhtin, M. 1979. Esthetics of speech art. Moscow).

---. 1979. Problemy poetiki Dostoevskogo. Moskva. (Bakhtin, M. 1979. Problems of Dostoevsky's poetics. Moscow).

---. 1984. Problems of Dostoevsky's Poetics. University of Minnesota Press.

---. 1986. Dialogical Imagination. University of Texas Press, Austin TX.

Barnett, M. 2005. "Social Constructivism.” In J. Baylis, S. Smith, eds., The Globalization of World Politics: An Introduction to International Relations ( $\left.3{ }^{\text {rd }} \mathrm{ed}\right)$. Oxford: Oxford University Press, 252-269.

Campbell, D. 2007. "Poststructuralism." In International Relations Theories: Discipline and Diversity, edited by T. Dunne, M. Kurki and S. Smith, 166-185. New York: Oxford University Press. 
Checkel, J. 2004. "Social Constructivisms in Global and European Politics." Review of International Studies 30 (2): 229-244.

DeBardeleben, J. 2008. "Public Attitudes toward EU-Russian Relations: Knowledge, Values, and Interests." In The Boundaries of EU Enlargement: Finding a Place for Neighbours, edited by J. DeBardeleben, 70-92. New York: Palgrave Macmillan.

Dostoyevsky, F., and D. Magarshack. 1971. The Devils (The Possessed). Penguin Classics.

Fierke, K. 2007. "Constructivism." In International Relations Theories: Discipline and Diversity, edited by T. Dunne, M. Kurki, and S. Smith, 166-185. New York: Oxford University Press.

Hansen, L. 2006. Security and Practice: Discourse Analysis and the Bosnian War. New York: Routledge.

Komitet "Rossiia v Ob'edinennoi Evrope”. 2005. Rossiia i Evropeiskiii Soiuz: ot krisiza k novomy dogovoru. Moskva. (Committee "Russia in the United Europe". 2005. Russia and the European Union: From Crisis to a New Treaty. Moskva).

Kratochwil, F. 1989. Rules, Norms and Decisions: On the Conditions of Practical and Legal Reasoning in International Relations and Domestic Affairs. Cambridge: Cambridge University Press.

---. 2001. "Constructivism as an Approach to Interdisciplinary Study." In Constructing International Relations, edited by K. Fierke and K. Jorgensen, 13-36. Armonk, New York: Sharpe.

Medvedev, S. 2008. "The Crisis in EU-Russia Relations: Between 'Sovereignty' and 'Europeanization'." Working paper WP14/2007/02/ Moscow: State University- Higher School of Economics.

Onuf, N. 1989. World of Our Making: Rules and Rule in Social Theory and International Relations. Columbia: University of South Carolina Press.

---. 1998. “Constructivism: A User's Manual.” In International Relations in a Constructed World, edited by N. Kubálková, N. Onuf, and P. Kowert, 58-79. USA: M.E. Sharpe, Inc.

Pashkovskaia, I. 2007. “Deiatel'nost' Evropeiskogo Soiuza v Rossii po programme TACIS.” Mirovaia Ekonomika I Mezhdunarodnye Otnosheniia 8: 42-51. (Pashkovskaia I. 2007. "Actions of the European Union in Russia under the TACIS program." World Economy and International Relations 8: 42-51.)

Prozorov, S. 2006. Understanding Conflict between Russia and the EU: The Limits of Integration. New York: Palgrave Macmillan.

Prozorov, S. 2009. The Ethics of Postcommunism: History and Social Praxis in Russia. New York: Palgrave Macmillan.

Reiss, T. 1982. The Discourse of Modernism, Ithaca NY: Cornell University Press.

Roach, S. ed. 2007. Critical Theory and International Relations. New York: Routledge.

Ruggie, J. 1998. "What Makes the World Hang Together? Neo-utilitarianism and the Social Constructivist Challenge." International Organization 52 (4): 855-885.

Searle, J. 1969. Speech Acts. An Essay in the Philosophy of Language. London: Cambridge University Press.

---. 1992. (On) Searle on Conversation. (Compiled and introduced by H. Parret \& J Verschueren), Amsterdam and Philadelphia, PA: John Benjamins.

Shotter, J. 1995. "In Conversation: Joint Action, Shared Intentionality and Ethics." Theory Psychology 5 (1): 49-73.

Wendt, A. 1999. Social Theory of International Politics. Cambridge: Cambridge University Press.

Zehfuss, M. 2002. Constructivism in International Relations: The Politics of Reality. New York: Cambridge University Press.

\section{KEY PRIMARY SOURCES}

Agreement on Partnership and Cooperation (1997). (JOCE L 327, 27/11/1997).

Common Strategy of the European Union of 4 June 1999 on Russia (L 157, 24/06/1999 P. 0001 - 0010). Accessed on October 15, 2009. http://ue.eu.int/en/summ.html 
EU's Country Strategy Paper 2007-2013: Russian Federation. Accessed on November 12, 2009. http://ue.eu.int/en/

Road Maps of Four EU-Russia Common Spaces 2007. Accessed on October 15, 2009. http://ec.europa.eu/comm/external_relations/russia/russia_docs/road_map_ces.pdf

The Russian Federation Middle Term Strategy Towards The European Union (2000-2010) 1999. Accessed on October 15, 2009. http://www.delrus.cec.eu.int/en/p_242.htm

\section{DOCTRINES, CONCEPTS AND SUMMITS}

Europa glossary: Petersburg Tasks. Accessed on November 15, 2009. http://europa.eu/scadplus/glossary/petersberg_tasks_en.htm

The European Commission Delegation official site: EU-Russia summit in Khanty-Mansiysk. June 2008. Accessed April 22, 2010. http://www.delrus.ec.europa.eu

The European Commission Delegation official site: TACIS, INTERREG. Accessed on April 22, 2010. http://www.delrus.ec.europa.eu

The Foreign Policy Concept of the Russian Federation 2000. Accessed on March 15, 2009. http://www.scrf.gov.ru/documents/25.html 